\title{
Comparison of two gene amplification methods for the detection of Toxoplasma gondii in experimentally infected sheep
}

\author{
J. M. WASTLING, S. NICOLL* and D. BUXTON
}

Moredun Research Institute, 408 Gilmerton Road, Edinburgh EH17 7JH and " Regional Virus Laboratory, The City Hospital, Edinburgh EH10 5SB

\begin{abstract}
Summary. Efferent lymph and peripheral blood collected from sheep experimentally infected with Toxoplasma gondii strain S48 were analysed for parasite DNA by amplification of the B1 and P30 T. gondii genes by the polymerase chain reaction (PCR). The relative sensitivity of these two gene amplification methods was assessed and compared with parasite detection by mouse injection (MI). B1 PCR was consistently more sensitive than P30 PCR and the results agreed closely with those from MI. By contrast, P30 PCR gave more than twice as many false negatives results than B1 PCR. The few apparent false positive results given by either PCR method were probably due to the inability of MI to detect non-viable parasites. All specimens collected before infection with $T$. gondii gave negative results by PCR and MI. Parasite DNA was detected by both B1 and P30 PCR in the lymph node of a sheep 12 days after infection but not in other tissues. The results permit a direct comparison between $T$. gondii detection by P30 and B1 PCR. Moreover, they further confirm the value of PCR detection of toxoplasma as a sensitive, specific and reliable diagnostic and research tool.
\end{abstract}

\section{Introduction}

Toxoplasmosis is a zoonosis caused by the protozoan parasite Toxoplasma gondii which has social and economic relevance to both human and animal medicine. Although for most healthy individuals infection is mild with few or no clinical symptoms, for vulnerable groups, such as immunocompromised individuals or the developing fetus, toxoplasmosis may prove lifethreatening. Therefore, rapid and accurate diagnosis is important. Serologically-based diagnostic techniques for patients who have serious immune dysfunction due to AIDS or through immunosuppressive drug therapy may prove unreliable because of impaired antibody production. Isolation of the parasite by mouse injection (MI) is time consuming and potentially hazardous.

The ability of gene amplification by the polymerase chain reaction (PCR) to detect small amounts of DNA suggests that it may prove to be a sensitive method for the diagnosis of toxoplasmosis. Methods based on amplification of either the P30 gene ${ }^{1}$ or the B1 gene $^{2}$ of $T$. gondii have been developed and used for the detection of toxoplasma in various clinical specimens. B1 gene amplification has been used to detect $T$. gondii in a limited number of specimens collected postmortem from immunocompromised patients and aborted human fetuses, ${ }^{3,4}$ as well as to diagnose toxoplasma infection in utero, suggesting its potential as a method for pre-natal diagnosis of congenital infection. ${ }^{5}$ P30 gene amplification has also been used to detect $T$. gondii in human fetal blood and amniotic fluid $^{6,7}$ and in brain tissue collected by biopsy from AIDS patients. ${ }^{8}$

Turner and Savva ${ }^{9}$ and Turner et al.$^{10}$ have reported, in uncontrolled field studies, the use of P30 gene amplification to identify equine ocular toxoplasmosis and to detect the parasite in organs and tissues of lambs aborted apparently following maternal toxoplasmosis. To date, however, the use of PCR for the detection of ovine toxoplasmosis has not been assessed under controlled experimental conditions. Furthermore, no attempt has been made to compare directly the relative efficacy of the P30 and B1 PCR detection methods.

A comparison of the $\mathrm{B} 1$ and $\mathrm{P} 30$ genes as targets for amplification by PCR for the detection of $T$. gondii in experimentally infected sheep is described in this paper. The study aimed to establish (1) whether one of the two PCR methods was more sensitive and to assess the extent of agreement with parasite detection by MI; (2) whether parasites could be detected in ovine peripheral blood as well as in lymph; (3) whether parasites could be detected in ovine solid tissues. 


\section{Materials and methods}

\section{Parasites}

$T$. gondii strain S48 tachyzoites (kindly supplied by H. Bos, Intervet B.V., The Netherlands) were grown in female Swiss White mice. The parasites were harvested with a 26 gauge needle and syringe from the peritoneal cavities of mice that had been infected 3 days earlier with $10^{6}$ tachyzoites by intraperitoneal injection. Tachyzoites were washed three times by suspension in $0.3 \mathrm{M}$ phosphate-buffered saline (PBS), $\mathrm{pH} 7.4$, followed by centrifugation at $500 \mathrm{~g}(5 \mathrm{~min})$ and counted with a haemocytometer at a magnification of 400 . Preparations with $<2 \%$ host cell contamination were used for infecting sheep.

\section{Experimental samples}

Lymph was obtained from sheep undergoing sampling for concomitant immunological analysis. Efferent lymph draining from the pre-femoral lymph node was collected by cannulation of the duct from six ewes seronegative for $T$. gondii. ${ }^{11,12}$ Each animal was infected with $10^{5} T$. gondii strain $\mathrm{S} 48$ tachyzoites ${ }^{13}$ by subcutaneous (s.c.) injection into the flank adjacent to the cannulated node. Lymph was examined before infection and daily thereafter up to 15 days postinfection. Each lymph sample was divided into three and tested for T. gondii by $\mathrm{MI}$ and by $\mathrm{B} 1$ and P30 PCR.

Peripheral blood was collected daily from a further group of three ewes which were initially seronegative for toxoplasma, before and after infection with $10^{5}$ $T$. gondii strain $\mathrm{S} 48$ tachyzoites s.c. The lymph nodes of these animals were not cannulated.

A ewe from which the flow of lymph had stopped prematurely after infection with $10^{5} T$. gondii strain S48 tachyzoites s.c., was killed 12 days post-infection and samples (c. $1 \mathrm{~g}$ ) of brain, spleen, diaphragm, liver, kidney and left and right pre-femoral lymph nodes were removed and prepared for PCR analysis.

\section{PCR}

Preparation of samples. Lymph was diluted 1 in 10 with PBS to prevent clotting and centrifuged at $800 \mathrm{~g}$ for $10 \mathrm{~min}$. Contaminating erythrocytes (RBC) were lysed by the addition of $1 \mathrm{ml}$ of $10 \mathrm{mM}$ Tris- $\mathrm{NH}_{4} \mathrm{Cl}$ and the remaining cells were washed three times by resuspension in PBS and centrifugation at $800 \mathrm{~g}$ for $10 \mathrm{~min}$. The resulting pellet was resuspended in $50 \mu \mathrm{l}$ of $10 \mathrm{mM}$ Tris, $\mathrm{pH} 8.3,50 \mathrm{mM} \mathrm{KCl}, 1.5 \mathrm{mM} \mathrm{MgCl}_{2}$ containing proteinase $\mathrm{K} 100 \mu \mathrm{g} / \mathrm{ml}$ and Tween 20 $0.5 \%$. After incubating the mixture at $55^{\circ} \mathrm{C}$ for $1 \mathrm{~h}$, proteinase was inactivated by boiling and the specimens were stored at $-20^{\circ} \mathrm{C}$.

Whole blood was treated to remove RBC. Leucocytes were separated from $\mathrm{RBC}$ by centrifugation over Lymphoprep (Nycomed, Oslo, Norway) and remaining $\mathrm{RBC}$ were lysed with $\mathrm{Tris}-\mathrm{NH}_{4} \mathrm{Cl}$ as above.
Leucocytes prepared from blood were treated with proteinase $\mathrm{K}$ and stored at $-20^{\circ} \mathrm{C}$.

Tissues were frozen before preparation. Each tissue was finely chopped and washed in PBS. Remaining $\mathrm{RBC}$ were lysed and the tissues were digested overnight at $37^{\circ} \mathrm{C}$ in $100 \mu \mathrm{l}$ of $50 \mathrm{mM}$ Tris ( $\mathrm{pH} 8.5$ ), $1 \mathrm{~mm}$ EDTA, Tween $200.5 \%$ containing proteinase $\mathrm{K} 200 \mu \mathrm{g} / \mathrm{ml}$. After digestion, the proteinase was inactivated by boiling and samples were stored at $-20^{\circ} \mathrm{C}$.

Reaction conditions. PCR was performed in $50-\mu 1$ volumes in a Techni PHC3 thermal cycler. Amplification of the P30 gene was performed according to the method of Savva et al. ${ }^{1}$ with a reaction mixture consisting of $10 \mathrm{~mm}$ Tris (pH 8.3), $50 \mathrm{~mm} \mathrm{KCl}, 1.5 \mathrm{mM}$ $\mathrm{MgCl}_{2}$, gelatin $0.01 \%, 0.2 \mathrm{~mm}$ dNTPs (Pharmacia), $0.2 \mu \mathrm{M}$ each primer (Oswel DNA services, Edinburgh) and 2.5 units of Taq polymerase (Boehringer Mannheim, Germany). Test sample $(5 \mu \mathrm{l})$ was added to the reaction mixture and a 30 cycle amplification process of $1 \mathrm{~min}$ at $95^{\circ} \mathrm{C}, 1.5 \mathrm{~min}$ at $60^{\circ} \mathrm{C}$ and $3 \mathrm{~min}$ at $74^{\circ} \mathrm{C}$ was performed with primers DS29 and DS30, followed by a further 15 cycles with nested primers DS38 and DS39 to give a final product of $522 \mathrm{bp}$. DNA was detected at concentrations of $0.1 \mathrm{pg}$ which gave a sharply defined band corresponding to about $500 \mathrm{bp}$ on an agarose $0.8 \%$ gel. Sensitivity was increased by Southern blotting to detect $0.05 \mathrm{pg}$ of DNA, corresponding approximately to the DNA content of one tachyzoite. ${ }^{1}$

Amplification of the B1 gene was performed by a method modified from that of Burg et al. ${ }^{2}$ The

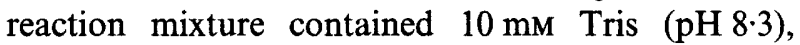
$2.5 \mathrm{mM} \mathrm{MgCl}_{2}, 40 \mathrm{mM} \mathrm{KCl}$, gelatin $0.01 \%, 0.1 \mathrm{~mm} \mathrm{~d}-$ NTPs, $0.2 \mu \mathrm{M}$ of each primer and 2.5 units of Taq polymerase. Primers P1, P3 and P4 were as described by Burg et al. ${ }^{2}$ but P2 consisted of only 20 bases, corresponding to nucleotides 757-776 of the $\mathrm{B} 1$ gene (Oswel DNA services). Amplification was performed with $\mathrm{P} 1$ and $\mathrm{P} 4$ to give a 193-bp product over 25 cycles of $93^{\circ} \mathrm{C}$ for $1 \mathrm{~min}, 50^{\circ} \mathrm{C}$ for $1.5 \mathrm{~min}$ and $72^{\circ} \mathrm{C}$ for $3 \mathrm{~min}$. Amplification products were then diluted 1 in 20 in distilled water to reduce amplification of nonspecific products and amplified again with nested primers P2 and P3 over 15 cycles to give a 94-bp product. With this method, $0 \cdot 05 \mathrm{pg}$ of DNA could be seen on an agarose $1 \%$ gel although resolution was much improved on a polyacrylamide $7.5 \%$ gel.

Negative controls consisting of distilled water and uninfected lymph and blood were run for each set of tests to monitor cross-contamination. General precautions to prevent cross-contamination included the use of positive displacement pipettes, disposable plastic ware and the wearing of latex gloves.

DNA extraction for controls. For positive controls, $10^{9} T$. gondii strain S48 tachyzoites were lysed in $50 \mathrm{~mm}$ Tris (pH 8.0), $50 \mathrm{~mm}$ EDTA, SDS $1 \%$, containing proteinase $\mathrm{K} 100 \mu \mathrm{g} / \mathrm{ml}$. After incubation for $3 \mathrm{~h}$, the nucleic acid was extracted with phenolchloroform, then precipitated with sodium acetateethanol at $-20^{\circ} \mathrm{C}$ and pelleted by centrifugation at 
$10000 \mathrm{~g}$ for $15 \mathrm{~min}$. The DNA pellet was washed in ethanol $70 \%$ and resuspended in TE $(10 \mathrm{mM}$ Tris, $0 \cdot 1$ mM EDTA, pH 7.6). RNA was removed by incubation with RNAase $20 \mu \mathrm{g} / \mathrm{ml}$ for $30 \mathrm{~min}$ at $37^{\circ} \mathrm{C}$ and the DNA was re-extracted and precipitated as above. The pellet was resuspended in $100 \mu \mathrm{l}$ of TE and the DNA quantified by measuring UV absorption at $260 \mathrm{~nm}$

For negative DNA controls, DNA was extracted by the above method from Sarcocystis sp. (kindly supplied by N. Lally, Centre for Tropical Veterinary Medicine, Edinburgh) and from Pneumocystis carinii obtained from the lungs of rats. ${ }^{14}$ DNA extractions from Candida albicans and Aspergillus niger were also performed. ${ }^{15,16}$ No amplification products were obtained from the DNA of any of these organisms with either P30 or B1 PCR.

\section{Electrophoresis and Southern blotting}

Amplification products were analysed routinely on agarose gels. Southern blotting was used to confirm the identity of the B1 and P30 PCR products and to distinguish these from non-specific products occasionally apparent when B1 and P30 PCR was performed on lymph samples. For Southern blotting, DNA products were transferred to Hybond membranes (Amersham, Bucks) and DNA-DNA hybridisation was performed with digoxygenin-labelled fragments produced from DS 38 and DS 39 for P30 products and from $\mathbf{P} 2$ and $\mathrm{P} 3$ for $\mathrm{B} 1$ products (DNA labelling and detection kit, Boehringer Mannheim).

\section{Detection of $T$. gondii in lymph by mouse injection}

Samples $(250 \mu \mathrm{l})$ of each specimen of lymph tested were injected intraperitoneally into each of three mature female Swiss White mice. Animals were inspected daily and those which appeared ill were killed a sample of peritoneal exudate was removed and inspected microscopically for tachyzoites. Serum was collected from mice which survived at 8 weeks after injection and was tested for the presence of toxoplasma antibodies by IgG ELISA. ${ }^{17}$

\section{Antibody detection}

Blood was collected daily from sheep and the serum was examined for $T$. gondii-specific antibody by ELISA. ${ }^{17}$

\section{Statistical analysis}

Data for parasite detection in lymph by PCR and MI was analysed by a generalised linear model ${ }^{18}$ with a binomial error term. This was programmed in the Genstat 5 programming language. ${ }^{19}$ Parasite detection in blood by B1 and P30 PCR was compared by a twotailed $t$ test.

\section{Results}

\section{Parasite detection in efferent lymph}

A total of 101 lymph specimens was collected from 4 days before infection up to 15 days post-infection and analysed for $T$. gondii by each detection method. The numbers of positive tests given by MI, and $\mathrm{B} 1$ and P30 PCR are shown in table I. T. gondii was isolated by MI from 29 samples collected between 3 and 12 days post-infection compared with 30 that were positive by B1 PCR and 20 by P30 PCR. For individual sheep, the mean total number of days in which samples gave positive results was 4.8 (SD 3.2) days with MI, 5.0 (SD 1.9) days with B1 PCR and 3.2 (SD 2.2) days with P30 PCR. T. gondii-specific antibody was not detected in the serum of any mouse that survived after injection of lymph.

The performance of B1 and P30 PCR detection was compared with MI for each lymph sample. Twentythree tests that were positive by MI were also positive by B1 PCR, whereas P30 PCR give 14 positive tests that were confirmed to be positive by MI. The numbers of false negative results, i.e., samples that were shown to be positive by MI but gave negative PCR results, were 15 with P30 PCR only but six with B1 PCR. Both PCR methods gave a small number of apparent false positive results (seven and six for B1 and P30 respectively); most of these occurred towards the end of infection. An estimate of the overall reliability of both B1 and P30 PCR detection compared with MI for all 101 samples showed an $87 \%$ agreement between MI and B1 PCR compared with $79 \%$ with P30 PCR. When the frequency of parasite detection by $\mathrm{B} 1$ or P30 PCR was compared with only those 29 samples shown to be positive by MI, the agreement between PCR and MI was $79 \%$ for B1 PCR but only $52 \%$ for P 30 PCR.

The results for the $\mathrm{B} 1$ and $\mathrm{P} 30$ methods were compared further by calculating the number of positive results scored for each method out of a total delimited by the "window" of positive results given by MI for each animal. After removing between-sheep variation, the difference between the $\mathrm{B} 1$ and $\mathrm{P} 30$ methods was statistically significant $\left(F_{1,4}=9 \cdot 320\right.$; $\mathrm{p}=0.038$ ).

\section{Parasite detection in blood}

Both the B1 and P30 PCR methods detected $T$. gondii DNA in the peripheral blood of the three sheep during infection with tachyzoites of strain S48. B1 PCR detected parasites over a mean of 4.7 (SD 0.6) days compared with 1.7 (SD 0.6) days with P30 PCR (table II). In each case, parasitaemia was detected earlier with B1 PCR and over a significantly longer time ( $p=0.003,4 \mathrm{df}$, two-tailed $t$ test). The infection became established in each of these animals and seroconversion took place after 11 days. Having established the close agreement between MI and B1 PCR in the previous experiment, isolation of the 
Table I. Comparison of B1 PCR, P30 PCR and MI for detection of T. gondii in lymph from infected sheep

\begin{tabular}{ccccc}
\hline & & \multicolumn{3}{c}{ Number of positive tests by } \\
\cline { 3 - 5 } Days post-infection & Number of sheep tested & MI & B1 PCR & P30 PCR \\
& & 0 & 0 & 0 \\
-4 & 2 & 0 & 0 & 0 \\
-3 & 5 & 0 & 0 & 0 \\
-2 & 5 & 0 & 0 & 0 \\
-1 & 6 & 0 & 0 & 0 \\
0 & 6 & 0 & 0 & 0 \\
1 & 6 & 0 & 0 & 0 \\
2 & 6 & 2 & 1 & 2 \\
3 & 6 & 4 & 4 & 5 \\
4 & 6 & 4 & 6 & 3 \\
5 & 6 & 4 & 5 & 2 \\
6 & 6 & 5 & 4 & 2 \\
7 & 5 & 4 & 4 & 2 \\
8 & 5 & 4 & 3 & 2 \\
9 & 5 & 1 & 1 & 1 \\
10 & 5 & 1 & 1 & 1 \\
11 & 5 & 0 & 1 & 0 \\
12 & 5 & 0 & 0 & 0 \\
13 & 5 & 0 & 0 & 0 \\
14 & 2 & 0 & 0 & 0 \\
15 & 101 (tests) & 29 & 30 & 20 \\
Total & & & & \\
\hline
\end{tabular}

Table II. Detection of $T$. gondii in the blood of three sheep by PCR and antibody detection by ELISA after experimental infection with $10^{5}$ tachyzoites of strain S48

\begin{tabular}{|c|c|c|c|c|c|c|c|c|c|c|c|c|c|c|c|}
\hline \multirow{2}{*}{ Sheep } & \multirow{2}{*}{ Test } & \multicolumn{14}{|c|}{ Result on days post-infection } \\
\hline & & 1 & 2 & 3 & 4 & 5 & 6 & 7 & 8 & 9 & 10 & 11 & 12 & 13 & 14 \\
\hline \multirow{3}{*}{ A } & B1 PCR & - & - & - & - & - & + & + & + & + & + & - & - & - & - \\
\hline & P30 PCR & - & - & - & - & - & - & + & + & - & - & - & - & - & - \\
\hline & ELISA & - & - & - & - & - & - & - & - & - & - & + & + & + & + \\
\hline \multirow{3}{*}{ B } & B1 PCR & - & - & - & - & - & + & + & + & + & - & - & - & - & - \\
\hline & P30 PCR & - & - & - & - & - & - & + & + & - & - & - & - & - & - \\
\hline & ELISA & - & - & - & - & - & - & - & - & - & - & + & + & + & + \\
\hline \multirow{3}{*}{$\mathrm{C}$} & B1 PCR & - & - & + & - & - & + & + & + & - & - & + & - & - & - \\
\hline & P30 PCR & - & - & - & - & - & - & + & - & - & - & - & - & - & - \\
\hline & ELISA & - & - & - & - & - & - & - & - & - & - & + & + & + & + \\
\hline
\end{tabular}

parasite by MI was not attempted for blood or tissue samples.

\section{Parasite detection in lymph node tissue}

The left and right pre-femoral lymph nodes from the sheep killed 12 days after infection were shown to be positive for $T$. gondii by both $\mathrm{B} 1$ and P30 PCR. Parasite DNA was not detected in the liver, spleen, brain, kidney or diaphragm by either method.

\section{Discussion}

In this study, amplification of either the B1 or P30 gene by PCR detected $T$. gondii in lymph, blood and lymph node samples from experimentally infected sheep, but the relative sensitivity of the two methods differed. In lymph, the agreement between parasite detection by MI and PCR was significantly higher with
B1 PCR than with P30 PCR. Detection by P30 PCR gave almost twice as many false negative results as $B 1$ PCR. Furthermore, parasites were detected in the peripheral blood of infected sheep both earlier and for a significantly longer period with B1 PCR than with P30 PCR.

Both $\mathrm{B} 1$ and P30 gene amplification gave a similar, but low, number of apparent false positive results. However, these may represent samples containing parasite DNA but no viable organisms since, unlike MI, PCR does not rely on live parasites to give a positive result. As none of the mice which survived until 8 weeks after injection with lymph produced antibody against $T$. gondii, it is concluded that only those that developed clinically apparent disease were exposed to tachyzoites. Apparent false positive results which occurred towards the end of infection may result from samples containing traces of parasite DNA but no viable tachyzoites. Furthermore, no positive 
PCR results were obtained in any of the lymph samples collected before infection or in any other negative control. The discrepancies between negative MI tests and positive PCR results were, therefore, probably due to constraints of MI detection rather than to genuine false positive PCR tests.

Although detection by amplification of the $\mathrm{B} 1$ gene was repeatedly more sensitive than that of the P30 gene, the absolute sensitivity of each method when applied to ovine lymph and blood remains to be determined. Moreover, a comparative investigation into the efficacy of P30 and B1 PCR with other clinical material, including human specimens, is required before any conclusions can be made about the use of either target gene for parasite detection in general. The preparations of whole blood for PCR by removal of RBC with Lymphoprep may require further improvement as this method would not isolate free parasites or those within cells remaining in the RBC fraction after centrifugation. Although this method minimises contamination of the specimen with haemoglobin it is time consuming and requires immediate treatment of samples before they can be frozen and stored.

The sensitivity of $\mathrm{B} 1$ amplification may be due to the repetitive nature of the $B 1$ gene, of which $25-50$ copies are present in the genome of $T$. gondii. ${ }^{20}$ Brezin et al. ${ }^{21}$ suggested that this might account for their successful use of B1 amplification to detect human ocular toxoplasmosis but failure with P30 PCR. Since amplification of a single specific fragment is sufficient to give a positive result, the repeated short DNA fragments of the $\mathrm{B} 1$ gene provide a better target than the longer single copy P30 gene. However, where the danger of cross-contamination is greater, the superior sensitivity of B1 PCR will require greater stringency in the laboratory to avoid predisposing the diagnosis to false positive results.

Both P30 and B1 PCR detected T. gondii in the lymph nodes from an infected animal even though the tissue had been frozen and thawed before analysis.

\section{References}

1. Savva D, Morris JC, Johnson JD, Holliman RE. Polymerase chain reaction for detection of Toxoplasma gondii. $J \mathrm{Med}$ Microbiol 1990; 32: 25-31.

2. Burg JL, Grover CM, Pouletty P, Boothroyd JC. Direct and sensitive detection of a pathogenic protozoan, Toxoplasma gondii, by polymerase chain reaction. J Clin Microbiol 1989; 27 : 1787-1792.

3. van de Ven E, Melchers W, Galama J, Camps W, Meuwissen J. Identification of Toxoplasma gondii infections by B1 gene amplification. J Clin Microbiol 1991; 29: 2120-2124.

4. Gross U, Roggenkamp A, Janitschke K, Heesemann J. Improved sensitivity of the polymerase chain reaction for detection of Toxoplasma gondii in biological and human clinical specimens. Eur J Microbiol Infect Dis 1992; 11: 33-39.

5. Grover CM, Thulliez P, Remington JS, Boothroyd JC. Rapid prenatal diagnosis of congenital toxoplasma infection using the polymerase chain reaction and amniotic fluid. $J$ Clin Microbiol 1990; 28: 2297-2301.

6. Johnson JD, Holliman RE, Savva D. Detection of Toxoplasma gondii using the polymerase chain reaction. Biochem Soc Trans 1990; 18 : 665 .

7. Dupouy-Camet J, Lavareda de Souza S, Bougnoux ME et al.
This contrasts with an earlier report by Weiss et al. ${ }^{22}$ who found that parasite detection in lymph node tissue frozen before analysis was unreliable compared with detection in paraffin-embedded sections. The reason for this discrepancy is not known. In the present study, the parasite was not detected by PCR in tissues other than lymph node. While this may reflect the genuine distribution of tachyzoites throughout the host, the possibility that freezing and thawing of some tissues may compromise the sensitivity of PCR cannot be excluded without further investigation of a larger number and range of tissue specimens.

By demonstrating the efficacy of PCR detection of $T$. gondii in a large number of clinical specimens under controlled experimental conditions, this study confirms the potential of PCR as a valuable technique for the detection of the parasite and suggests the value of an ovine model for the assessment of PCR diagnosis of human toxoplasmosis. For instance, the ability to monitor tachyzoites in peripheral blood may be of use in the detection of reactivated human toxoplasmosis associated with immune dysfunction. Moreover, the capability of PCR to monitor the kinetics of $T$. gondii in body fluids such as lymph and blood suggests that PCR will prove a valuable experimental tool for the study of the pathogenesis of toxoplasmosis in both man and animals. In these instances, B1 PCR would seem to be the method of choice because of its exquisite sensitivity that is not apparently compromised by false positive results. Furthermore, the sensitivity of PCR will enable gene amplification to replace $\mathrm{MI}$ as the standard method for direct detection of $T$. gondii, thus dispensing with the use of large numbers of mice.

The authors are grateful to $\mathrm{H}$. Bos of Intervet B.V., The Netherlands, for supplying $T$. gondii strain S48. The authors also acknowledge the expert assistance of Mrs $\mathrm{K}$. Thomson and $\mathrm{Mr}$ S. Maley for specimen collection and ELISA tests and thank F. Wright of Scottish Agriculture Statistics Service for help with statistical analysis. J.M.W. was supported under the Flexible Funding Scheme of the Scottish Office Agriculture and Fisheries Department. S.N. was supported by the Medical Research Council (SPG 9022510).

Preventing congenital toxoplasmosis (letter). Lancet 1990 ; 336: 1018 .

8. Holliman RE, Johnson JD, Savva D. Diagnosis of cerebral toxoplasmosis in association with AIDS using the polymerase chain reaction. Scand J Infect Dis 1990; 22: 243-244.

9. Turner CB, Savva D. Detection of Toxoplasma gondii in equine eyes (letter). Vet Rec 1991; $129: 128$.

10. Turner CB, Mohammed D, Savva D. Detection of toxoplasma DNA in ovine samples (letter). Vet Rec 1991; $129: 436$.

11. Hall JG, Morris B. The output of cells in lymph from the popliteal node of sheep. $Q J$ Exp Physiol 1962;47:360-369.

12. Huang H-S, Buxton D, Burrells C, Anderson IE, Miller HRP. Immune responses of the ovine lymph node to Chlamydia psittaci. A cellular study of popliteal efferent lymph. $J$ Comp Pathol 1991; 105: 191-202.

13. Wilkins MF, O'Connell E, Te Punga WA. Toxoplasmosis in sheep 1. Effect of a killed vaccine on lambing losses caused by experimental challenge with Toxoplasma gondii. $\mathrm{NZ} \mathrm{Vet}$ J 1987; 35: 31-34.

14. Dyer M, Volpe F, Delves CJ, Somia N, Burns S, Scaife JG. Cloning and sequence of a $\beta$-tubulin cDNA from Pneumocystis carinii: possible implications for drug therapy. $\mathrm{Mol}$ Microbiol 1992; 6: 991-1001.

15. Monod M, Porchet S, Baudraz-Rosselet F, Frenk E. The 
identification of pathogenic yeast strains by electrophoretic analysis of their chromosomes. J Med Microbiol 1990; 32: 123.

16. Denning DW, Clemons KV, Hanson LH, Stevens DA. Restriction endonuclease analysis of total cellular DNA of Aspergillus fumigatis isolates of geographically and epidemiological diverse origin. $J$ Infect Dis 1990; 162: 1151-1158.

17. Buxton D, Blewett DA, Trees AJ, McClogan C, Finlayson J. Further studies in the use of monensin in control of experimental ovine toxoplasmosis. J Comp Pathol 1988; 98: 225 .

18. McCullagh P, Nelder JA. Generalized linear models. New York, Chapman and Hall. 1983.
19. Payne RW, Lane PW, Ainsley AE et al. Genstat 5 reference manual. Oxford, Clarendon Press. 1988.

20. Boothroyd JC, Burg JL, Nagel S et al. In: Agabian N, Goodman H, Nogueira N (eds) Molecular strategies of parasitic invasion. New York, A.R. Liss. 1987: 237-250.

21. Brezin AP, Egwuagu CE, Burnier et al. Identification of Toxoplasma gondii in paraffin-embedded sections by the polymerase chain reaction. Am J Ophthalmol 1990; 110: 599-604.

22. Weiss LM, Chen Y-Y, Berry GJ, Strickler JG, Dorfman RF, Warnke RA. Infrequent detection of Toxoplasma gondii genome in toxoplasmic lymphadenitis: a polymerase chain reaction study. Hum Pathol 1992; 23: 154-158. 